\title{
THE FACE OF ISLAM POST 2019 PRESIDENTIAL ELECTION: DEMOCRACY AND THE CHALLENGE OF DIALOGUE
}

\author{
MUHAM M AD RADYA YUDANTIASA \\ Center for Religious and Cross-cultural Studies (CRCS), Gadjah Mada University (UGM) Email: yudantiasa@gmail.com
}

\begin{abstract}
This article examines the problems of intra/interreligious dialogue that occurred after the 2019 presidential election. The focus of this study is to analyse the impact of Islamic populism on the sustainability of dialogue in Indonesia. The trend of Islamic populism is basically narrative and analytic of Indonesian political studies. The political contestation has an impact on the intra/inter-religious dialogue problems or even transcending ethnic and group boundaries. This situation requires intense dialogue among scholars, activists, elites, religious leaders and society members. This research is a library research using descriptive-analysis method. The main theory in this research is agonistic theory. This theory sees the conflict from more positive ways. This article argues that the discourse and the narration of moderate Islam needs to be brought into public sphere. Hence, the peaceful characters of Islam and tolerant Islam become the dominant colors of Islam in the public sphere.
\end{abstract}

KATA KUNCI: dialogue, contestation, presidential election, Islamic populism

\section{WAJAH ISLAM PASCA PEMILIHAN PRESIDEN 2019: DEMOKRASI DAN TANTANGAN DIALOG}

\begin{abstract}
Abstrak
Artikel ini mengungkap kembali problematika tentang dialog pasca pemilihan presiden 2019. Fokus dari artikel ini adalah untuk menganalisis pengaruh dari populisme Islam terhadap keberlanjutan dialog di Indonesia. Tren dari populisme Islam pada dasarnya merupakan sebuah narasi dan analisis yang banyak dikaji dalam lingkup studi politik di Indonesia. Peristiwa kontestasi politik yang terjadi di dalam pemilihan presiden 2019 menunjukkan adanya permasalahan terhadap dialog dalam/antar agama dan bahkan melampaui batas-batas etnik maupun kelompok agama. Situasi ini meniscayakan para aktor-aktor dialog dari kalangan akademisi, aktivis, elit politik, pemuka agama, dan masyarakat untuk terlibat dalam kontestasi ini. Penelitian ini merupakan studi kepustakaan (library research) dengan menggunakan metode deskriptif-analisis. Teori utama yang digunakan dalam artikel ini adalah teori agonistik (agonistic theory). Teori ini berfungsi untuk melihat konflik dalam sudut pandang yang positif. Artikel ini menyimpulkan bahwa klaim tentang wacana dan narasi Islam yang moderat harus muncul untuk dikontestasikan dalam ruang publik. Dengan demikian, wajah asli Islam yang damai, toleran dan rahmatan lil-'alamin akan menjadi wajah yang dominan dalam ruang publik.
\end{abstract}

KatA KunCI: dialog, kontestasi, pemilu, demokrasi, populisme Islam

\footnotetext{
* Naskah diterima Februari 2020, direvisi April 2020, dan disetujui untuk diterbitkan Mei 2020
} 


\section{A. Pendahuluan}

Jose Casanova dalam bukunya "Public Religions in the Modern World" mengajukan sebuah tesis tentang de-privatisasi agama. Tesis ini membuktikan bahwa de-privatisasi merupakan gambaran tentang kebangkitan agama yang diindikasikan dengan semua tradisi agama menolak untuk dimarginalisasikan (Casanova, 1994: 6). Agama tidak hanya mengurusi persoalan yang berkaitan dengan teologi saja (privatized sphere), tetapi agama mulai terlibat dalam berbagai macam diskusi tentang politik, ekonomi, sosial, dan budaya (public sphere). Fenomena ini terjadi di berbagai belahan dunia, termasuk Indonesia. Pasca keruntuhan Orde Baru yang ditandai dengan turunnya Soeharto sebagai presiden, Indonesia mulai babak baru dalam menjalankan kehidupan demokrasi. Dalam konteks ini, salah satu tanda yang paling mencolok adalah munculnya kelompok-kelompok Islam yang variatif. Kemunculan kelompok-kelompok ini tentu menjadi fenomena yang tidak bisa dibiarkan begitu saja. Mereka hadir bukan tanpa visi dan misi yang ingin dicapai.

Populisme Islam merupakan sebutan yang digunakan untuk melabeli kelompok-kelompok tersebut. Secara sederhana, berkembangnya kelompok ini menjadikan Islam sebagai alat politik untuk tujuan tertentu. Kelihaian dalam memainkan isu-isu agama menjadi kekuatan tersendiri dalam mencapai tujuan mereka. Faktor inilah yang membuat pemahaman publik menjadi tidak jelas sehingga susah dipisahkan antara area politik dan agama. Situasi tersebut mendukung populisme Islam masuk ke dalam ruang publik (Jati, 2017: 21). Puncak dari kemunculan kelompok ini adalah momen pesta demokrasi yang diselenggarakan lima tahun sekali di Indonesia yaitu pemilihan presiden 2019. Penulis berargumen bahwa momen ini adalah sumber dari konflik, segregasi, dan skisma. Mengapa? Karena momen ini menyebabkan kontestasi politik yang tidak sehat. Hoaks, ujaran kebencian, dan politik identitas merupakan cara-cara yang digunakan untuk menyulut permasalahan yang menyebabkan keretakan.

Membahas pemilihan presiden 2019 tidak bisa dilepaskan dari rangkaian-rangkaian dari orkestrasi politik yang terjadi sebelumnya. Orkestrasi politik ini melibatkan banyak aktor yang bermain di dalamnya, seperti elit politik, kelompok keagamaan, dan juga masyarakat. Dalam hal ini, masyarakat adalah kelompok yang paling terdampak dalam kontestasi politik tersebut. Hal ini bisa terjadi karena tidak semua masyarakat memahami peristiwa ini dengan pandangan yang luas. Banyak masyarakat yang tersulut emosinya baik secara dogmatis maupun psikologis karena isu-isu keagamaan yang sengaja digunakan untuk memecah belah masyarakat. Sebagai contoh, terjadinya kerusuhan akibat ketidakpuasan atas hasil dari pemilihan presiden 2019 mengakibatkan enam orang terbunuh dan dua ratus lainnya luka-luka akibat demo yang terjadi pasca pengumuman hasil yang disampaikan oleh Komisi Pemilihan Umum (KPU). Dalam lingkup yang lebih sempit, perpecahan antar tetangga terjadi akibat berbeda pilihan presiden. Dua contoh tersebut adalah sebagian kecil dari banyaknya contoh konflik yang terjadi.

Gambaran ini menunjukkan bahwa "suara" umat Islam sangat berperan dalam situasi tersebut. Namun, situasi ini sangat kompleks dan tidak hanya melibatkan umat Islam saja. Dampak dari "orkestrasi politik" tersebut melewati batasbatas agama, etnik, dan kelompok keagamaan. Dampak dari pemilihan presiden 2019 menimbulkan permasalahan dialog agama. Artikel ini berusaha untuk meninjau kembali teoriteori tentang dialog dalam situasi "konflik". Pertanyaan besarnya adalah bagaimana peran dialog dalam situasi tersebut?

Artikel ini memahami relasi antara dialog dan konflik sebagai hubungan dialektik (a dialectic relationship). Memang, terdapat konsep umum yang menyatakan bahwa relasi antara dialog dan konflik sebagai suatu oposisi bahkan kontras dan dikotomis. Konsekuensi dari pandangan ini adalah dialog dianggap sebagai sesuatu yang "suci" yang menjadi tujuan dari kehidupan damai. Sedangkan konflik dipandang sebagai sesuatu yang "profan" sehingga ia harus dijauhi atau bahkan ditinggalkan karena ia memiliki asosiasi yang negatif. Penulis dalam hal ini mengikuti argumen yang digunakan oleh Bertram-Troost. Menurutnya, konflik bisa menjadi basis untuk terciptanya dialog (Bertram-Troost, Gerdien, Julia Ipgrave, Dan-Paul Jozsa, 2008: 405). Maka dari itu, konflik harus dipandang sebagai sesuatu yang positif sebagai partner dialog. Singkat kata, kita butuh konflik untuk keberlangsungan dialog. 


\section{B. Metode Penelitian}

Tulisan ini adalah penelitian berbasis studi kepustakaan (library research). Metode yang digunakan adalah deskriptif-analisis. Penelitian ini merupakan kombinasi antara studi tentang demokrasi dan studi tentang dialog keagamaan. Literatur-literatur yang dikumpulkan kemudian dianalisis dengan menggunakan teori.

Teori yang digunakan dalam artikel ini adalah teori "dialog agonistik". Pada dasarnya, agonistik merupakan istilah yang populer dalam proses demokrasi di mana konflik menjadi elemen utama (Mouffe, 2013). Teori ini memandang dialog sebagai fenomena yang berhubungan dengan perbedaan, konflik, dan ketidaksepakatan. Selain itu, teori ini berfungsi untuk meruntuhkan relasi kuasa. Sebagaimana yang dikatakan oleh Gergen and Barret, dialog memungkinkan otoritas untuk diperdebatkan, berbagai macam opini untuk diekspresikan, dan realitas yang diterima apa adanya untuk dibebaskan. Lebih lanjut, artikel ini menggunakan mazhab Bakhtinian yang menggunakan dua cara untuk melihat dialog agonistik yaitu diakronik dan sinkronik. Penulis akan menjelaskan dua model dialog ini di akhir pembahasan. Pada dasarnya dua model ini menekankan kepada perbedaan bentuk dan cara memahami keterbukaan (Ganesh \& Zoller, 2012: 78).

\section{Hasil dan Pembahasan}

Demokrasi Sebagai Panggung Kontestasi

"Kita bangsa Indonesia telah menunjukkan bahwa Islam, demokrasi, dan modernitas dapat tumbuh secara simultan"

Tesis ini diungkapkan oleh Presiden keenam Republik Indonesia, Susilo Bambang Yudhoyono (SBY) dalam salah satu jurnal yang berjudul "The Democratic Instinct in the $21^{\text {st }}$ Century". Dia memprediksi bahwa era ini merupakan panggung bagi suara Islam yang moderat, toleran, dan terbuka. Lebih lanjut, ia mengatakan bahwa abad ke-21 bukan merupakan abad dari perbenturan peradaban. Penulis berargumen bahwa prediksi SBY di satu sisi benar, tetapi di sisi lain bisa juga salah. Benar karena memang wajah Islam yang moderat dan toleran selalu dinarasikan setidaknya dalam satu dekade terakhir ini. Salah karena kemunculan kelompok Islam populis membuktikan sebaliknya. Kontestasi yang dimaksud di sini adalah perebutan wacana keislaman antar kelompok Islam.

Demokrasi itu sendiri pada dasarnya menyediakan ruang untuk kontestasi. Memang ada beberapa pandangan untuk mendisiplinkan kontestasi tersebut. Dalam konteks ini pun, demokrasi mungkin bisa dimanfaatkan untuk kepentingan tertentu. Penulis mendukung demokrasi sebagai panggung kontestasi. Pandangan ini membuka peluang besar untuk menghidupkan kembali kehidupan berdemokrasi. Meskipun konsekuensi dari pilihan tersebut menimbulkan efek negatif yang cukup serius sebagaimana yang akan dibahas nanti, tetapi itulah tanggung jawab sebuah pilihan. Lalu, bagaimana demokrasi dipahami sebagai panggung kontestasi?

Artikel ini menggunakan teori dari Chantal Mouffe untuk menjelaskan situasi ini. Dia menggunakan istilah demokrasi agonistik. Dalam demokrasi model ini, kontestasi adalah keniscayaan, di mana musuh politik harus dipandang sebagai musuh "sementara" yang tidak harus dimusnahkan. Pandangan ini dikutip dari kalimat, "Kontestan politik saling bertarung satu dengan lainnya karena mereka ingin tafsir mereka tentang prinsip-prinsip demokrasi menjadi hegemoni" (Mouffe, 2013: 7). Cara pandang ini sebenarnya merupakan prinsip demokrasi yang radikal dan Mouffe mengatakan bahwa konflik merupakan harga mati bagi kehidupan demokrasi (Mouffe, 1999).

Kehadiran populisme Islam menjadikan dinamika Islam di Indonesia memiliki gaya dan nuansa yang berbeda. Kelompok ini berkembang dengan sangat pesat dan memungkinkan untuk menciptakan otoritas baru di luar dua otoritas yang sebelumnya dipegang oleh dua organisasi Islam besar yaitu Nahdlatul Ulama (NU) dan Muhammadiyah (Bruinessen, 2013:3). Contohnya adalah munculnya Gerakan Nasional Pengawal Fatwa Ulama (GNPF-U) yang berusaha untuk membangun otoritas baru sebagai tandingan dari otoritas-otoritas yang telah ada sebelumnya. Dalam konteks ini, kehadiran GNPF-U meramaikan panggung kontestasi dalam kehidupan demokrasi di Indonesia.

Pandangan penulis terhadap tesis SBY di atas sebenarnya berbasis pada fakta tersebut. Narasinarasi Islam yang moderat dan toleran yang sebelumnya dimanifestasikan oleh dua organisasi Islam terbesar di Indonesia (NU dan 
Muhamadiyah) mendapatkan tantangan dari kelompok-kelompok Muslim populis baru dengan cara menarasikan wajah Islam yang "sangat Islami" (Akmaliah, 2019: 137). Deskripsi ini menunjukkan bahwa fenomena kontestasi antar kelompok Muslim yang memiliki pandangan keagamaan yang berbeda adalah nyata. Pertanyaannya di sini adalah bagaimana peran dialog dalam situasi seperti ini? Apakah dialog mengharuskan untuk mendamaikan konflik antar kelompok keagamaan dengan cara "merelakan" salah satu pihak untuk mengalah? Atau dengan cara lain, menggunakan otoritas negara untuk "mendisiplinkan" salah satu pihak?

Jawabannya adalah tergantung paradigma dan analisis yang digunakan. Jikalau kita memandang dialog dan konflik sebagai sesuatu yang berbeda atau dengan kata lain dialog sebagai sesuatu yang positif dan konflik sebagai sesuatu yang negatif, maka cara penyelesaiannya cenderung mendisiplinkan konflik tersebut. Namun, paradigma Chantal Mouffe tidak seperti itu. Menurutnya, situasi ini justru mengharuskan konflik tersebut eksis sebagai basis dari terciptanya dialog. Artikel ini bertujuan untuk menganalisis lebih lanjut dari paradigma yang dibangun oleh Mouffe dengan mengobservasi kasus "orkestrasi politik" yang puncaknya terjadi pada pemilihan presiden 2019.

Dari penjelasan di atas, maksud dari demokrasi sebagai panggung kontestasi sudah cukup jelas. Kembali kepada argumen dari Mouffe, musuh politik harus dianggap sebagai lawan sementara. Dengan kalimat yang lebih radikal, kita bisa mengatakan bahwa siapa yang paling kuat adalah mereka yang akan jadi pemenang. Jadi, kontestasi yang dimaksud di sini adalah kontestasi berbagai macam wacana dan isu meliputi agama, politik, sosial, ekonomi, dan lainnya terutama dalam ruang media sosial. Tujuan dari kontestasi tersebut adalah untuk mendominasi wacana di ruang publik. Semuanya tergantung siapa kelompok yang memenangkan kontestasi tersebut.

\section{Populisme Islam: Meninjau Ulang Narasi yang Variatif}

Populisme Islam adalah istilah baru dalam kajian sosial politik di Indonesia. Istilah ini secara umum digunakan untuk menunjukkan sebuah ideologi dan gerakan yang mengatasnamakan rakyat. Melanjutkan tesis dari Jose Casanova di atas, kelompok ini berupaya untuk membangun kesadaran umat menggunakan wacana atau ide "Islam" agar bisa bangkit di ruang publik. Wasisto mendefinisikan populisme Islam sebagai bagian dari upaya untuk mempopulerkan dan menumbuhkan Islam sebagai prinsip, norma, dan nilai yang termanifestikan dalam lingkungan sosial dan politik (Jati, 2017: 22). Vedi R. Hadiz dalam bukunya, "Islamic Populism in Indonesia and the Middle East" mengatakan bahwa munculnya komunitas Muslim yang bervariasi tersebut pada dasarnya memiliki tujuan yang serupa. Di bawah "romantisme Islam", gerakan tersebut lahir sebagai perjuangan atas ekspresi kritik atas ketidakadilan yang diakibatkan oleh sistem yang ada. Mereka termarginalisasikan dalam rasa "tertindas" sehingga semangat persamaan ini yang pada akhirnya melahirkan populisme Islam model baru (Garadian, 2017: 382).

Pada bagian ini, ada beberapa pertanyaan yang akan dibahas yaitu apa yang sebenarnya mereka perjuangkan? Cara-cara apa yang mereka lakukan untuk menyukseskan tujuannya?

Dalam konteks Indonesia, istilah populisme Islam merujuk kepada beberapa momen "orkestrasi politik" mulai dari pemilihan presiden 2014, pemilihan gubernur Jakarta 2017, dan puncaknya pada pemilihan presiden 2019. Sebagai warga Indonesia, kita menyaksikan bagaimana polarisasi yang terjadi antara dua kubu yang melibatkan banyak elemen mulai dari elit politik, tokoh agama, dan juga masyarakat sipil yang menjadikan suasana menjadi semakin panas dan kompleks. Situasi di atas menjadi "sumber" konflik yang menyebabkan masalah dialog agama. Kasus penodaan agama (al-Maidah: 51) yang melibatkan Basuki Tjahaja Purnama (Ahok) dan polarisasi "cebong" dan "kampret" merupakan contoh permasalahan dialog. Kasuskasus tersebut semakin cepat berkembang karena didukung oleh perkembangan media sosial sehingga informasi (benar atau salah) tidak bisa terbendung.

Wahyudi menunjukkan bahwa ada dua narasi besar antara "Islamis" dan "Nasionalis" yang berkembang di masyarakat. Isu-isu yang melibatkan agama, etnik, dan kelompok keagamaan mulai muncul semenjak pemilihan presiden 2014 (Akmaliah, 2019: 136). Kasus majalah "Obor Rakyat" menjadi salah satu 
contohnya. Narasi yang diungkap oleh Obor Rakyat telah memainkan peran dalam menguatkan polarisasi antar kelompok. Mereka menyebut salah satu calon presiden Joko Widodo sebagai keturunan Tionghoa, calon presiden boneka, dan keturunan PKI (Partai Komunis Indonesia). Kasus lainnya, pada tahun 2016, adalah gerakan 212 yang digunakan sebagai gerakan intervensi untuk memperkarakan Ahok karena kasus penodaan agama. Gerakan tersebut cenderung berhasil karena pada tahun 2017 Ahok divonis hukuman penjara. Pada tahun yang sama, Kementerian Hukum dan HAM mencabut status badan hukum ormas Hizbut Tahrir Indonesia (HTI). Penulis berargumen bahwa kasus dan kebijakan di atas memperkuat polarisasi antar kelompok.

Polarisasi yang semakin tajam tersebut tampak dari berkembangnya politik identitas sebagai instrumen kontestasi yang dapat secara instan menjatuhkan eksistensi kubu yang berbeda. Belajar dari fenomena-fenomena di atas, kekuatan populisme Islam memiliki peran yang besar dalam mempengaruhi atau bahkan mengintervensi pilihan masyarakat. Wacana "umat" sebagai strategi politik berhasil memobilisasi dukungan dari warga Muslim. Situasi ini menjadi kesempatan yang tepat bagi kaum populis untuk melakukan dikotomi terhadap masyarakat secara moralitas dan identitas dalam kacamata Islam. Konstruksi "umat bermoral" melawan "rezim zalim" menjadi dasar untuk mengidentifikasi keberpihakan antara mana kelompok yang membela Islam dan kelompok yang berpihak kepada rezim yang zalim. Fenomena di atas telah menunjukkan kekuatan Islam yang transformatif sebagai sebuah corak politik yang dominan (Margiansyah, 2019: 59).

Penulis berargumen bahwa dominasi tersebut tidak statis tetapi dinamis. Artinya, kekuatan Islam akan selalu berkontestasi karena ada banyak wajah Islam di sana. Sebagai contoh, kontestasi wacana antara GNPF-U (Gerakan Nasional Pengawal Fatwa Ulama) dan Nahdlatul Ulama (NU). GNPF-U merupakan sebuah gerakan yang memotori "Aksi Bela Islam" dan berhasil menghimpun umat Islam untuk melakukan protes terhadap kasus penodaan agama. Dalam konteks ini, mereka sukses menciptakan otoritas baru yang mengklaim dirinya sebagai perwakilan umat Islam. Di sisi lain, Nahdlatul Ulama (NU) hadir sebagai sebuah organisasi besar untuk menghadang dominasi dari GNPF-Ulama yang pada dasarnya dipelopori juga oleh ormas Islam, seperti FPI (Front Pembela Islam) dan FUI (Forum Umat Islam). Dua kelompok ini menggunakan narasi yang berbeda untuk mendapatkan perhatian publik.

Narasi-narasi dari kaum populis tidak bisa dilepaskan dari tiga hal yaitu figur pemimpin karismatik, partai politik, dan pergerakan. Tiga komponen utama tersebut sangat menentukan keberhasilan operasionalisasi politik populis, termasuk cara mereka untuk menarasikan dirinya di hadapan publik. Strategi yang mereka gunakan juga berbasis pada instrumen demokratis dan konstitutional. Mereka menggunakan strategi mobilisasi rakyat dengan bergantung pada pengeksploitasian narasi dan retorika yang berpusat pada kedaulatan rakyat sebagai basis legitimasi politik (Margiansyah, 2019: 51). Tiga komponen tersebut juga merupakan kolaborasi antara institusi formal dan informal. Kolaborasi ini bisa menjadi sebuah kekuatan yang cukup kuat. Pada bagian ini, penulis ingin menekankan pada pengeksploitasian narasi dan retorika yang mereka gunakan sebagai instrumen untuk melakukan propaganda. Argumentasi dalam artikel ini berdasar kepada fakta tersebut sehingga perebutan wacana (khususnya wacana Islam) sangat menentukan narasi apa yang akan menjadi konsumsi publik.

\section{Dari Kontestasi Politik Menuju Permasalahan Dialog Agama}

Harold H. Saunders mengatakan bahwa manajemen konflik dan politik tidak akan bisa berjalan mulus tanpa melibatkan dimensi kemanusiaan. Lebih lanjut, ia berargumen bahwa institusi-institusi formal seperti negara dan pemerintah tidak akan mampu berdiri sendiri kecuali melibatkan dimensi kemanusiaan. Dimensi ini mencakup kelompok agama dan etnik. Keterlibatan dimensi ini membuka peluang untuk mempertimbangkan kebijakan sebagai proses yang tidak hanya terbatas pada kerja pemerintah. Menurutnya, model seperti ini akan berguna sebagai sebuah kekuatan untuk mengubah pola-pola relasi dalam konflik (Saunders, 1999: 8).

Ada dua kemungkinan ketika kontestasi 
politik masuk ke dalam dimensi kemanusiaan. Pertama, sebagaimana argumen Saunders di atas, dimensi yang dialamatkan kepada masyarakat sipil ini mampu mengubah konflik ke arah yang lebih baik. Kedua, kebalikan dari pendapat sebelumnya, konflik akan berubah semakin memburuk. Apalagi elit-elit politik bergabung dengan masyarakat sipil, seperti pemuka agama, organisasi-organisasi informal, dan kelompokkelompok yang lainnya, maka situasinya akan lebih kompleks. Situasi ini terjadi dalam sejarah politik di Indonesia, khususnya peristiwa pemilihan presiden 2019. Pada bagian ini, penulis akan mengeksplorasi bagaimana transisi dari kontestasi politik kepada problematika dialog agama.

Dalam sejarah pemilu di Indonesia, pada awalnya hanya ada tiga kontestan partai yang diizinkan untuk berpartisipasi di dalamnya. Tiga partai itupun diatur dengan aturan-aturan yang ketat, misalnya semua harus mengikuti ideologi yang sama yaitu Pancasila. Tiga partai itu adalah Golkar (Golongan Karya), PPP (Partai Persatuan Pembangunan), dan PDI (Partai Demokrasi Indonesia). Pada saat itu, Golkar berhasil menggapai suara terbanyak dengan $74.5 \%$ suara (Eklof, 1997: 1181). Situasi saat itu tentu sangat berbeda jika dibandingkan dengan sekarang. Namun, benih-benih dari tensi politik sudah mulai muncul pada saat itu. Menariknya, konflik tersebut malah muncul dari internal masingmasing partai. Contohnya, konflik yang terjadi di dalam internal partai PPP karena ada ketidaksepahaman. Hal ini bisa terjadi karena hanya ada satu partai yang merupakan "representasi Islam", maka perebutan wacana Islam terjadi dalam internal partai itu. Konflik internal ini juga terjadi di PDI.

Seiring berjalannya waktu, situasi ini pun berubah. Saat ini, Indonesia telah memiliki banyak partai dengan berbagai macam representasi budaya. Masing-masing partai memiliki "ideologi" atau tepatnya tafsir ideologi yang berbeda-beda meskipun mereka masih dalam satu ideologi Pancasila. Poin paling penting adalah mereka semua memiliki tujuan dan kepentingan. Hal ini menjadikan kontestasi antar partai akan semakin kompleks. Kondisi ini menjadi semakin parah melihat fakta pluralitas Indonesia yang cukup rentan untuk dipecah belah oleh kelompokkelompok yang tidak bertanggung jawab hanya demi kepentingan mereka saja. Selain itu, pengalaman yang berbeda-beda dalam setiap daerah juga menjadi senjata yang ampuh untuk melakukan propaganda politik.

Salah satu contoh daerah yang memiliki pengalaman khusus adalah Maluku. Daerah ini sangat rawan terjadi perpecahan antar agama mengingat konflik agama yang terjadi pada tahun 1999-2002 antara Islam dengan Kristen. Pada tahun-tahun tersebut, sentimen antara MuslimKristen sangat tinggi. Penekanan terhadap identitas agama dan simbol-simbol keagamaan pada masa politik menyebabkan kontestasi semakin meningkat. Van Klinke mengatakan bahwa sentimen yang tinggi menyebabkan tindak kekerasan yang dimobilisasi oleh orang-orang yang buta politik (Tomsa, 2009: 235). Menurut penulis, pola-pola transisinya bisa ditebak. Mulai dari konflik berubah menjadi politik, kembali menjadi konflik dan seterusnya. Jadi, pola-polanya selalu berkesinambungan. Ada tiga hal yang menyebabkan konflik tersebut semakin meningkat yaitu keterlibatan para elit politik, peran media dalam menyampaikan informasi, dan tumbuhnya hasrat untuk balas dendam terhadap musuh (Tomsa, 2009: 236).

Meskipun dari tahun 2003 Maluku mulai melakukan rekonsiliasi dan penormalan daerah kembali, pola-pola ini bisa saja muncul di daerahdaerah lain dengan gaya yang berbeda dan cara menghadapi yang berbeda. Peristiwa orkestrasi politik yang telah dijelaskan di atas adalah contoh kasus dengan pola-pola yang mirip dengan peristiwa di Ambon. Terlebih, peristiwa ini mungkin bisa dikategorisasikan sebagai permasalahan nasional meskipun peristiwa tersebut terjadi di daerah tertentu. Secara sederhana, tiga peristiwa politik besar (pemilihan presiden 2014, pemilihan gubernur Jakarta 2017, dan pemilihan presiden 2019) menjadi basis terjadinya masalah dialog agama. Polanya bisa dari kontestasi politik ke problematika dialog dan sebaliknya. Intinya, apapun dasarnya, peristiwa tersebut menyebabkan masalah dalam dialog.

Isu populisme Islam ini menemukan momentumnya pada tiga peristiwa politik yang telah disebutkan sebelumnya. Kelompok ini bahkan berhasil mencapai tujuan mereka yaitu menjatuhkan Ahok pada pemilihan Gubernur Jakarta 2017. Front Pembela Islam (FPI) yang dipimpin oleh Rizieq Shihab sukses memimpin 
aksi bela Islam berjilid jilid dengan tiga isu krusial yang menjadi pemicu mobilisasi massa yaitu etnis Tionghoa, penista agama, dan kafir. Tiga isu tersebut memiliki dampak yang signifikan tehadap beberapa aliansi masyarakat sehingga mereka merasa memiliki tanggung jawab untuk membela agamanya yang dicela. Keberhasilan dari kelompok populis ini juga didukung oleh perkembangan media sosial. Perkembangan dari media sosial sangat krusial dalam memainkan isuisu yang digunakan oleh kelompok populis. Aksi ini pun berlanjut pada pemilihan presiden 2019. Mereka ingin mengulang kembali kejayaan mereka pada saat menggulingkan Ahok. Tren yang mereka gunakan masih sama yaitu isu-isu agama. Klaim-klaim Muslim populis sebagai kelompok yang mewakili Islam muncul di ruang publik. Mereka melakukan dikotomi antara proIslam dan anti-Islam. Seperti contohnya, partai koalisi yang di dalamnya terdapat Gerindra, Partai Kesejarteraan Sosial (PKS), Demokrat, dan Partai Amanat Nasional (PAN) mereka anggap partaipartai yang membela Islam. Sedangkan partaipartai lainnya adalah partai yang mendukung penista agama (anti-Islam).

Siapa yang berhak berbicara atas nama Islam? Suara siapa yang lebih dominan? Artikel ini mengelaborasi dua skenario yang ditawarkan oleh Esposito and Mogahed. Dua skenarionya adalah aktif dan pasif. Aktif yang dimaksud adalah mayoritas Muslim mainstream terlibat secara aktif dalam menyuarakan wacana Islam yang damai. Dalam skenario ini, relasi antara Islam dan demokrasi dipandang secara resiprokal. Islam mendukung demokrasi yang dipercaya dapat menjunjung tinggi nilai-nilai, norma-norma, dan aturan-aturan keagamaan. Skenario ini juga tidak berarti mereka mendukung upaya sekularisasi. Namun, mereka menggunakan model demokrasi yang mencoba mengombinasikan antara nilainilai nasionalisme dan keagamaan.

Sedangkan pasif adalah mayoritas Muslim mainstream cenderung memilih untuk diam dan tidak bersikap sehingga suara mereka kalah dengan kelompok Muslim populis. Pada dasarnya, kelompok Muslim populis sebenarnya tidak memiliki populasi yang besar, tetapi mereka sangat vokal. Dalam skenario ini, Islam cenderung dipahami sebagai penyebab radikalisasi, kekerasan, dan tindakan terorisme (Esposito \& Mogahed, 2008: 54). Maka dari itu, penjelasan ini membuktikan bahwa suara Muslim populis cukup mendominasi ruang publik dan berhasil mempengaruhi banyak kalangan masyarakat.

\section{Alternatif Teori Untuk Memahami Dialog}

Bagian ini akan mengelaborasi argumenargumen yang berkaitan dengan tantangan dialog dalam situasi konflik berdasarkan data-data di atas. Penulis menggunakan demokrasi agonistik sebagai framework diskusi dalam artikel ini. Kata "agonism" berasal dari bahasa Greek yaitu agôn yang bermakna kontestasi atau perebutan. Menurut Wenman, teori demokrasi agonistik dibangun atas dasar pluralisme konstitutif. Dalam pandangan ini, teori demokrasi agonistik tidak hanya sekedar rekognisi terhadap perbedaan antar kelompok secara umum saja, tetapi juga masuk kepada sesuatu yang cukup fundamental yaitu perbedaan identitas kelompok dan individu (Davidson, 2016: 147).

Sarah Maddison \& Rachael Diprose mengatakan bahwa pengalaman historis menjadi elemen yang krusial sebagai sebuah wadah bagi masing-masing kelompok untuk melanjutkan "polarisasi" di antara mereka. Mereka menggunakan studi kasus di Indonesia yaitu peristiwa konflik di Poso. Aktor-aktor dialog memiliki kontribusi yang penting untuk mengintegrasikan dan mentransformasikan konflik. Pemerintah (pusat dan daerah), pemuka agama, dan masyarakat merupakan aktor-aktor dialog yang membantu untuk memahami lebih baik bagaimana setiap individu dan kelompok terlibat di dalam konflik (Maddison \& Diprose, 2018: 1633). Konflik di Poso dengan kasus orkestrasi politik yang telah dijelaskan di atas memiliki persamaan, khususnya adalah mereka mendapatkan pengalaman yang bermacammacam dalam setiap individu maupun kelompok yang berpartisipasi di dalam konflik. Situasi tersebut berubah setiap waktu sesuai dengan kacamata sejarah sosial-politik dalam konteks lokal dan nasional. Dalam hal ini, situasi yang paling berubah adalah peran media sosial yang memiliki dampak signifikan terhadap permainan isu-isu seputar politik, agama, dan lainnya.

Dialog agonistik mencoba untuk bergerak lebih jauh dari sekedar pencarian konsensus sebagai sebuah solusi. Konsensus pada dasarnya adalah sebuah terobosan yang cukup diminati oleh banyak sarjana. Namun, dalam konteks ini, 
konsensus cenderung untuk memarginalkan pandangan-pandangan yang lain atau lebih tepatnya suara-suara minoritas. Untuk itu, teori agonistik hadir untuk mengkritik teori tentang konsensus. Bagi para penganut teori agonistik, ketidaksepakatan adalah sebuah keniscayaan. Teori ini mempersilahkan pandangan-pandangan lain meskipun itu adalah suara minoritas karena esensi dari teori ini adalah upaya untuk memahami ide-ide lain yang tidak terjamah. Dari sini, ketidaksepakatan bisa dipahami sebagai sumber dari keberlangsungan demokrasi (Little, 2007: 154-5).

Penulis menggunakan cara pandang Bakhtinian dalam memahami dialog agonistik. Dia mengusulkan dua cara dalam memahami dialog. Dialog dan konflik dapat didekati secara diakronik dan sinkronik. Dalam perspektif diakronik, dialog dan konflik memiliki keterikatan secara interaktif dan pragmatis. Dialog dilihat sebagai gambaran dari keterbukaan. Sedangkan dalam perspektif sinkronik, dialog dan konflik dipahami sebagai ruang kontestasi yang berfungsi untuk meruntuhkan relasi kuasa melalui cara-cara yang argumentatif, konfrontatif, bahkan irasional untuk mengungkap alternatif-alternatif lain. Pada dasarnya, keduanya menekankan kepada seni untuk memahami keterbukaan.

Dalam konteks demokrasi, terdapat tiga orientasi tentang dialog yaitu kolaboratif, kooptatif, dan agonistik. Artikel ini memilih model agonistik karena model ini fokus terhadap pergeseran dasar-dasar dialog yang menekankan kepada kekuasaan, identitas, dan kerentanan. Selain itu, model ini memberikan perhatian yang lebih terhadap problematika tentang keadilan dan perubahan sosial (Ganesh \& Zoller, 2012: 77). Jadi, model agonistik mengistimewakan konflik sebagai elemen fundamental dalam perubahan sosial. Dalam definisi yang klasik, agonistik pada awalnya dipahami sebagai turnamen olahraga. Turnamen ini adalah sebuah area untuk berkontestasi secara fair dan terbuka. Semua memiliki kemungkinan untuk memenangkan pertandingan. Para kontestan bertanding untuk mencapai sebuah kemenangan (Davidson, 2016: 148). Kontestasi inilah yang menjadikan turnamen menjadi semakin hidup dan dinamis. Dalam konteks ini, tidak ada pihak yang diunggulkan (superior) dan dikucilkan (inferior), semua berpotensi menjadi pemenang. Dengan kata lain, jika Anda ingin menjadi pemenang, maka silahkan mempersiapkan cara yang paling baik untuk menjadi pemenang.

Untuk memahami fenomena yang telah dijelaskan, pendekatan sinkronik lebih tepat untuk digunakan. Mengapa? Berdasarkan definisi singkat di atas, pendekatan ini menurut penulis memberikan ruang pemahaman terhadap keterbukaan yang lebih "radikal". Dengan perspektif ini, setiap kelompok dapat menawarkan perubahan-perubahan etika melalui relasi publik. Tensi antar kelompok keagamaan tidak dipandang sebagai sesuatu yang negatif. Tetapi, ia harus dipandang secara seimbang untuk melanjutkan pola-pola dialog yang lebih dinamis (Ganesh and Zoller, 2012, p. 80)

Kembali ke kasus, cara pandang di atas melihat kehadiran populisme Islam sebagai fenomena yang positif. Teori agonistik menyediakan ruang bagi mereka untuk turut meramaikan kontestasi politik. Dengan demikian, wajah Islam menjadi semakin beragam dalam pemilihan presiden 2019. Pada awalnya, penulis merasa cukup kebingungan untuk melihat situasi saat terjadi kontestasi politik dalam pemilihan presiden 2019. Namun, teori ini membantu untuk melihat secara lebih luas bagaimana cara memahami kontestasi tersebut. Kehadiran Muslim populis menjadikan nuansa kehidupan demokrasi negara ini menjadi semakin hidup. Terlepas dari berbagai macam kritik, teori ini berguna untuk self-reminder bagi masa pemerintahan yang sedang berlangsung.

Dengan cara berpikir klasik, kita bisa mengimajinasikan pertarungan politik tersebut sebagai sebuah kompetisi yang fair. Masingmasing kelompok memiliki cara dan strategi untuk memenangkan pilihan politiknya. Apapun caranya, termasuk humor, ironi, atau bahkan provokasi merupakan cara yang bisa diperdebatkan, diperjuangkan, dan dikontestasikan. Mereka berlomba untuk mendapatkan perhatian publik. Muslim populis juga hadir dalam rangka untuk memenangkan kontestasi tersebut. Dengan pendekatan ini, lawan politik juga harus siap dengan kehadiran kelompok ini. Semua harus siap dengan strateginya masing-masing.

Secara umum, pengaruh Muslim populis cukup signifikan dalam mengambil perhatian publik. Model Islam yang mereka tawarkan 
berhasil menggerakkan massa dengan jumlah yang cukup besar. Diam adalah pilihan yang tidak tepat bagi kelompok-kelompok Islam moderat. Semakin mereka diam dan merasa bahwa dominasi mereka masih kuat, maka populisme Islam akan semakin kuat. Maka dari itu, penulis berargumen bahwa kelompok-kelompok Islam moderat harus terlibat dalam persaingan ini. Tidak ada cara lain kecuali merebut kembali wacana-wacana Islam yang toleran, moderat, dan rahmatan lil 'alamin.

\section{Kesimpulan}

Kehadiran kelompok Muslim populis sebagai salah satu tren dalam gerakan Islam memberikan nuansa baru dalam sejarah perpolitikan di Indonesia. Kelompok ini semakin menguat sejak diselenggarakannya beberapa momen politik seperti pemilihan presiden 2014, pemilihan gubernur Jakarta 2017 dan pemilihan presiden 2019. Salah satu ciri dari kelompok ini adalah mereka cukup lihai dalam memainkan isu-isu agama dalam momen-momen politik yang terjadi. Selain itu, mereka juga berhasil dalam merebut otoritas keagamaan yang sebelumnya telah didominasi oleh NU dan Muhammadiyah. Artikel ini menunjukkan bahwa kontestasi politik yang terjadi telah menyebabkan masalah dialog yang melewati batas-batas agama, suku, dan ras. Masalah ini menjadi isu utama yang dibahas dalam keseluruhan artikel. Meskipun demikian, Artikel ini berargumen bahwa kehadiran populisme Islam merupakan suatu hal yang positif, bahkan meningkatkan kehidupan berdemokrasi di Indonesia.

Secara sekilas, artikel ini terlihat kontradiktif. Di satu sisi, menunjukkan bahwa kontestasi politik itu menyebabkan masalah dialog dan di sisi yang lain menunjukkan bahwa kontestasi politik adalah sesuatu yang positif. Dalam kesimpulan ini, penulis akan menjelaskan beberapa poin untuk menjelaskan argumen dalam artikel ini. Pertama, kontestasi politik yang menyebabkan masalah dialog adalah sebuah realitas. Pembahasan dalam artikel ini sudah menjelaskan secara teoritis maupun praktis beberapa contoh permasalahan dialog. Dari fenomena tersebut, konseptualisasi masalah dan teori memiliki pengaruh yang signifikan. Penulis menggunakan "teori agonistik" untuk melihat fenomena tersebut secara lebih luas. Teori inilah yang menjadi alasan fundamental kenapa kontestasi politik dapat dilihat sebagai sesuatu yang positif.

Terakhir, artikel ini berargumen bahwa kontestasi politik adalah panggung kompetisi. Dialog tidak harus terjadi dalam situasi yang "suci", tetapi ia juga bisa dilakukan dalam situasi yang "profan". Maka dari itu, cara untuk memenangkan kontestasi tersebut adalah ikut terlibat dalam situasi ini dan menyiapkan strategi terbaik. Dengan kontestasi ini, wacana dan narasi yang menunjukkan wajah Islam yang moderat bisa diperebutkan kembali dalam ruang publik.

\section{UCAPAN TERIMAKasiH}

Pertama, penulis mengucapkan terima kasih kepada Direktorat Pendidikan Tinggi Islam (Diktis) Kementerian Agama Republik Indonesia yang telah memberikan beasiswa studi selama dua tahun (empat semester) di Center for Religious and Cross-cultural studies (CRCS), Universitas Gadjah Mada (UGM). Kedua, terima kasih kepada Zainal Abidin Bagir selaku dosen pengampu mata kuliah Religion, State, and Society dan Fatimah Husein serta Izak Y.M. Lattu selaku dosen pengampu mata kuliah Interreligious Dialogue yang telah memberikan ide, gagasan, serta wacana-wacana kritis dalam perkuliahan sehingga memberikan inspirasi kepada penulis untuk menulis artikel ini. Terakhir, terima kasih kepada Jurnal Dialog yang telah memberikan kesempatan kepada penulis untuk menyampaikan ide dan gagasan sederhana sehingga tulisan singkat ini dapat dibaca oleh publik. 
Akmaliah, W. (2019). Kebenaran yang Terbelah/ : Populisme Islam dan Disinformasi Politik Elektoral. Arus Pemikiran Islam Dan Sosial, 14(01), 134-155.

Bertram-Troost, Gerdien, Julia Ipgrave, Dan-Paul Jozsa, and T. K. (2008). European Comparison: Dialogue and Conflict. In T. Knauth (Ed.), Encountering Religious Pluralism in School and Society: a qualitative study of teenage perspectives in Europe. Munchen: Waxmann Verlag.

Bruinessen, M. van. (2013). Introduction: Contemporary Developments in Indonesian Islam and the "Conservative Turn" of the Early Twenty-Firts Century. In M. van Bruinesssen (Ed.), Contemporary Developments in Indonesian Islam: Explaining the" conservative Turn. Singapore: Institute of Southeast Asian Studies.

Casanova, J. (1994). Public Religions in the Modern World. In Public Religions in the Modern World. https://doi.org/10.7208/chicago/ 9780226190204.001.0001

Davidson, S. (2016). Public relations theory: An agonistic critique of the turns to dialogue and symmetry. Public Relations Inquiry, 5(2), 145-167. https://doi.org/10.1177/ 2046147X16649007

Eklof, S. (1997). The 1997 General Election in Indonesia. University of California Press, 37(12), 1181-1196.

Esposito, J. L., \& Mogahed, D. (2008). Who will speak for Islam? World Policy Journal, 25(3), 47-57. wopj.2008.25.3.47

Ganesh, S., \& Zoller, H. M. (2012). Dialogue, activism, and democratic social change. Communication Theory, 22(1), 66-91. https:// doi.org/10.1111/j.1468-2885.2011.01396.x

Garadian, E. A. (2017). Membaca Populisme Islam Model Baru. Studia Islamika, 24(2). https:// doi.org/10.15408/sdi.v24i2.5708

Jati, W. R. (2017). Dari Umat Menuju Ummah?:
Melacak Akar Populisme Kelas Menengah Muslim Indonesia Wasisto Raharjo Jati Abstrak. Jurnal Arus Pemikiran Islam Dan Sosial, 5(2), 22-36.

Little, A. (2007). Between disagreement and consensus: Unravelling the democratic paradox. Australian Journal of Political Science, 42(1), 143-159. https://doi.org/ 10.1080/10361140601158591

Maddison, S., \& Diprose, R. (2018). Conflict dynamics and agonistic dialogue on historical violence: a case from Indonesia. Third World Quarterly, 39(8), 1622-1639. h t t p s : / / d o i.org / 10.1080 / 01436597.2017.1374837

Margiansyah, D. (2019). Populism in Contemporary Indonesia: Transformation of Competing Populisms and Its Consequences in Political Contestation Dynamics toward the 2019 Election. Jurnal Penelitian Politik (LIPI), 16(1), 47-68. https:/ /doi.org/http://ejournal.politik.lipi.go.id/ index.php/jpp/article/view/782

Mouffe, C. (1999). Deliberative democracy or agonistic pluralism? Social Research, 66(3), 745-758.

Mouffe, C. (2013). Agonistics: Thinking the World Politically. London: Verso.

Saunders, H. H. (1999). A Public Peace Process Sustained Dialogue to Transform Racial and Ethnic Conflicts. https://doi.org/10.1017/ CBO9781107415324.004

Tomsa, D. (2009). Electoral democracy in a divided society the 2008 gubernatorial election in Maluku,Indonesia. South East Asia Research, 17(2), 229-259. https://doi.org/10.5367/ 000000009788745877 
